Rohovyi Yurii, Tsitrin Volf, Bilooka Yula, Arkchipova Ludmila, Bilookiy Vyacheslav. Mechanism of influence of molecular hydrogen on the function of the proximal tubule of the nephron in irritatable bowel syndrome. Journal of Education, Health and Sport. 2021;11(2):53-62. eISSN 2391-8306. DOI http://dx.doi.org/10.12775/JEHS.2021.11.2.006

https://apcz.umk.pl/czasopisma/index.php/JEHS/article/view/JEHS.2021.11.2.006

https://zenodo.org/record/4540211

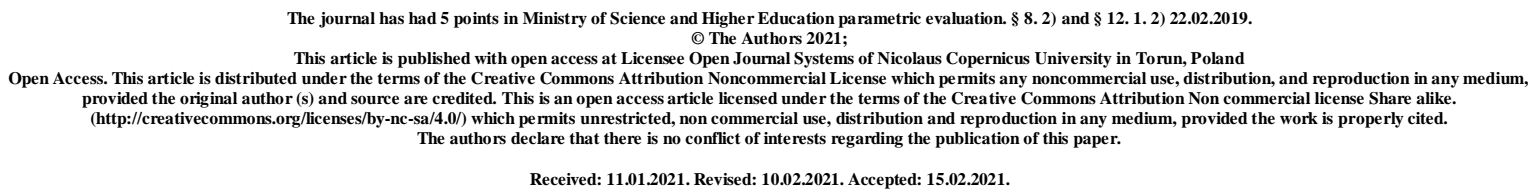

UDC: 612.466:616.613-002-007.271-07

\title{
MECHANISM OF INFLUENCE OF MOLECULAR HYDROGEN ON THE FUNCTION OF THE PROXIMAL TUBULE OF THE NEPHRON IN IRRITATABLE BOWEL SYNDROME
}

\author{
Yurii Rohovyi ${ }^{1}$, Volf Tsitrin ${ }^{1}$, Yula Bilooka ${ }^{1}$, Ludmila Arkchipova ${ }^{2}$, \\ Vyacheslav Bilookiy ${ }^{1}$
}

\author{
${ }^{1}$ Bukovinian State Medical University, Chernivtsi, Ukraine \\ ${ }^{2}$ Regional municipal institution "Chernivtsi oblast clinical hospital”, Chernivtsi, Ukraine
}

Yurii Rohovyi - Chief of the department pathological physiology the Bukovinian State Medical University, Chernivtsi, Ukraine.

Volf Tsitrin - Postgraduate of the department pathological physiology the Bukovinian State Medical University, Chernivtsi, Ukraine.

Yula Bilooka - Postgraduate of the department internal medicine and infectious diseases the Bukovinian State Medical University, Chernivtsi, Ukraine.

Ludmila Arkchipova - Physician reflexologist regional municipal institution "Chernivtsi oblast clinical hospital", Chernivtsi, Ukraine.

Vyacheslav Bilo'okiy -Professor of the Department of Surgery the Bukovinian State Medical University, Chernivtsi, Ukraine.

\section{Abstract}

Aim. To find out a pathophysiological protective role of influence of molecular hydrogen on a functional condition of a proximal tubule of kidneys at an irritable bowel syndrome.

Materials and methods. 60 patients with irritable bowel syndrome were examined. Men - 18, women - 42 aged from 28 to 62 years. Of which: with irritable bowel syndrome with constipation were - 28 patients, irritable bowel syndrome with diarrhea - 32 . The control 
group consisted of 25 almost healthy patients. General clinical (Likert scale), functional (proximal reabsorption of sodium ions in the kidneys), enzyme-linked immunosorbent assay (concentration of cytokines in blood plasma: tumor necrosis factor- $\alpha$, interleukin-1 $\beta$, interleukin-6), microbiological (population levels of anaerobic B. Bifidum, B. lactis in $\mathrm{lg}$ $\mathrm{CFO} / \mathrm{g}$ in the lumen of the colon), biochemical (the total, enzymatic fibrinolytic activity of urine) research methods were used.

All patients received molecular hydrogen in the form of an aqueous solution in the amount of 1 liter per day in four doses of $250 \mathrm{ml}$ for 7 days with a concentration of $\mathrm{H}_{2} 1.0$ $1.2 \mathrm{ppm}$ and redox potential from -250 to $-350 \mathrm{mV}$, which was obtained using a generator of a new generation of antioxidant solution saturated with hydrogen Blue Water 900 (Korea), mode 1. Statistical data processing was performed using computer programs "Statgrafics" and "Exel 7.0".

Results and discussion. The protective effect of molecular hydrogen improves the functional state of the proximal renal tubule in irritable bowel syndrome due to its high permeability and selective antioxidant activity against hydroxyl radical and peroxynitrite, which contributes to the rupture of large and small vicious circles in the combined pathological process.

Key words: proximal tubule; water diuresis; renal function; molecular hydrogen; irritable bowel syndrome.

INTRODUCTION. Irritable bowel syndrome according to the IV Roman Consensus is known to be a functional bowel disease with recurrent abdominal pain associated with bowel movements or changes in stool type, such as diarrhea or constipation, and flatulence. These symptoms appear at least 6 months before diagnosis and occur periodically during the last three months, with the frequency of abdominal pain should be at least once a week [1,2]. In the pathogenesis of irritable bowel syndrome can play a significant role proinflammatory cytokines with the formation of inflammasome [3], changes in which can lead to increased inflammatory process with activation of lipid peroxidation and renal dysfunction, because the proximal nephron is very sensitive to active forms of oxygen [4].

On the other hand, it is known that molecular hydrogen has selective antioxidant, antiinflammatory and anti-apoptotic properties, inhibits oxidative stress, atherosclerosis, prevents cognitive impairment, has a hepatoprotective effect, protects against the harmful effects of ischemia-reperfusion. $\mathrm{H}_{2}$ can be used as an effective antioxidant therapy; due to its ability to diffuse rapidly through membranes, it can penetrate the mitochondria and react with the most dangerous cytotoxic reactive oxygen species, such as hydroxyl radical, peroxynitrite, and thus 
protect against oxidative damage phospholipids of membranes, proteins, manifestations of inflammation and apoptosis $[6,7]$.

Aim. To find out a pathophysiological protective role of influence of molecular hydrogen on a functional condition of a proximal tubule of kidneys at an irritable bowel syndrome.

METHODS. 60 patients with irritable bowel syndrome were examined. Men - 18, women - 42 aged from 28 to 62 years. Of which: with irritable bowel syndrome with constipation were - 28 patients, irritable bowel syndrome with diarrhea - 32. Control group 25 almost healthy patients. General symptoms (summary assessment of symptoms: pain, bloating, frequency of defecation) in patients with irritable bowel syndrome were evaluated on a seven-point Likert scale [1,2]. The functional state of the kidneys was studied under water load. Patients consumed tap water heated to a temperature of $37^{\circ} \mathrm{C}$ in the amount of $2 \%$ of body weight. The amount of diuresis (V) was estimated in $1 / 2 \mathrm{~h} \cdot 1.72 \mathrm{~m}^{2}$ of body surface area. After water loading to obtain plasma, blood from a vein was collected in tubes with heparin. In plasma of blood and urine concentration of creatinine on reaction with picric acid, sodium ions by a method of a photometry of a flame on FPL-1 was defined. Calculated the proximal reabsorption of sodium ions $\left(\mathrm{T}^{\mathrm{p}} \mathrm{Na}^{+}\right)$by the formula: $\mathrm{T}^{\mathrm{p}} \mathrm{Na}^{+}=\left(\mathrm{C}_{\mathrm{cr}}-\mathrm{V}\right) \cdot \mathrm{PNa}^{+}$; where $\mathrm{C}_{\mathrm{cr}}$ is the glomerular filtration rate, $\mathrm{V}$ is diuresis, $\mathrm{PNa}^{+}$is the concentration of sodium ions in blood plasma [5, 8]. Population levels of anaerobic (B. Bifidum, B. lactis.) in lg CFO/g in the lumen of the colon were determined [9]. Studies of the concentration of cytokines in blood plasma: tumor necrosis factor- $\alpha$, interleukin- $1 \beta$, interleukin- 6 were performed by enzymelinked immunosorbent assay using kits from Diaclone (France) [10]. Fibrinolysis of urine was assessed by determining the lysis of azofibrin with the assessment of total (TFA), nonenzymatic (NFA) (incubation of samples in the presence of a blocker of enzymatic fibrinolysis $\varepsilon$-aminocaproic acid) and enzymatic fibrinolytic activity (EFA), which was calculated by the formula: $\mathrm{EFA}=\mathrm{TFA}-\mathrm{NFA}[5,8]$.

All patients received molecular hydrogen in the form of an aqueous solution in the amount of 11 per day in four doses of $250 \mathrm{ml}$ for 7 days with a concentration of $\mathrm{H}_{2} 1.0-1.2$ ppm and redox potential from -250 to $-350 \mathrm{mV}$, which was obtained using a generator of a new generation of antioxidant solution saturated with hydrogen Blue Water 900 (Korea), mode 1 .

All studies were performed in compliance with the "Rules of ethical principles of scientific medical research with human participation", approved by the Declaration of Helsinki (1964-2013), ICH GCP (1996), EEC Directive №609 (dated 24.11.1986), orders of 
the Ministry of Health of Ukraine № 690 dated 23.09.2009. № 944 dated 14.12.2009, № 616 dated 03.08.2012. Statistical data processing was performed using computer programs "Statgrafics" and "Exel 7.0".

RESULTS. The development of irritable bowel syndrome with constipation and diarrhea led to an increase in the level of pro-inflammatory cytokines in the blood plasma: interdeukin-1-beta, interleukin -6, tumor necrosis factor -alpha. The use of molecular hydrogen led to the correction of the detected changes (Fig. 1).

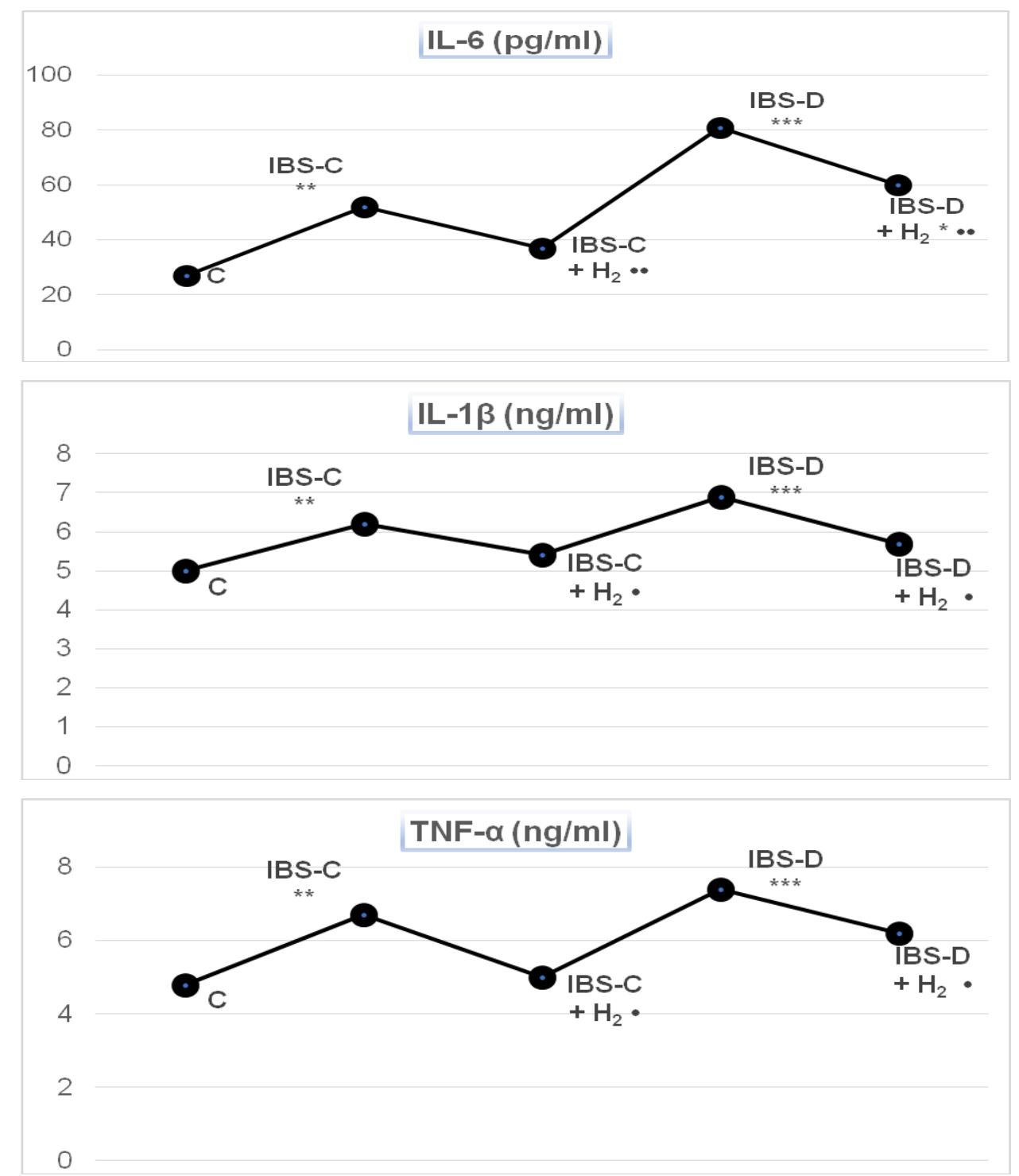

Fig. 1. Influence of molecular hydrogen $\left(\mathrm{H}_{2}\right)$ on the concentration of cytokines in blood plasma in patients with the development of irritable bowel syndrome with constipation (IBS-

C) and diarrhea (IBS-D). The probability of differences was noted in comparison: before control (C): * $-\mathrm{p}<0,05 ; * *-\mathrm{p}<0.02$; *** $-\mathrm{p}<0.01$; to irritable bowel syndrome with constipation and diarrhea $\bullet-\mathrm{p}<0,05$. 
The use of molecular hydrogen led to the correction of the detected violations. The study of the indicators of total and enzymatic fibrinolytic activities of urine showed inhibition of these parameters in the urine in irritable bowel syndrome with constipation and diarrhea. These disorders were combined with inhibition of proximal reabsorption of sodium ions in the kidneys in irritable bowel syndrome with constipation and diarrhea. The use of molecular hydrogen led to the correction of the detected changes (Fig. 2).
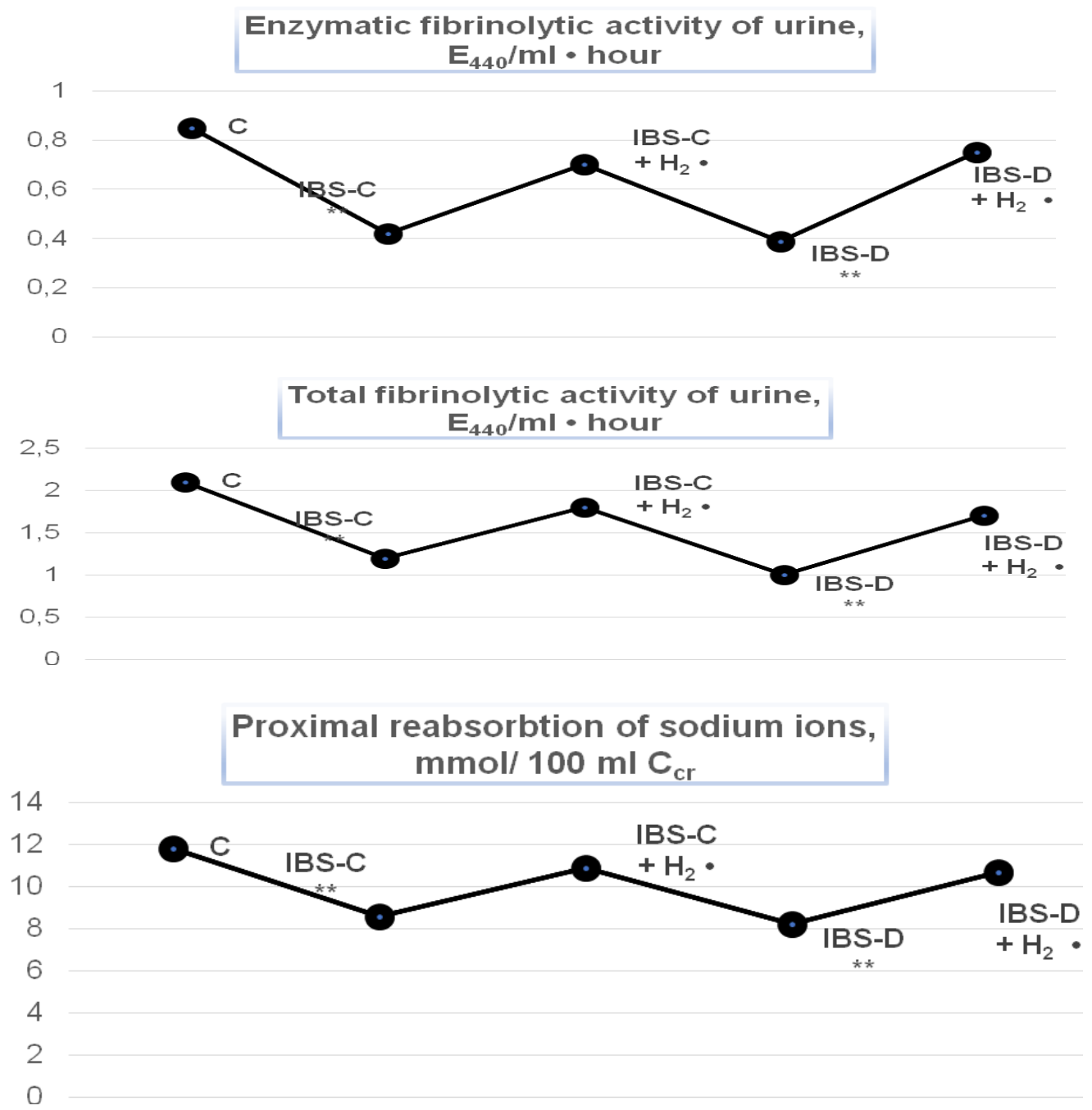

Fig. 2. Influence of molecular hydrogen $\left(\mathrm{H}_{2}\right)$ on the total, enzymatic fibrinolytic activity of urine and proximal reabsorbtion of sodium ions of kidneys in patients with the development of irritable bowel syndrome with constipation (IBS-C) and diarrhea (IBS-D). The probability of differences was noted in comparison: before control (C): ** - p <0.02; to irritable bowel syndrome with constipation and diarrhea $\bullet-p<0,05$. 
Assessment of the general condition of the patient on the Likert scale showed a deterioration in patients with irritable bowel syndrome with constipation and diarrhea, which was accompanied by a quantitative increase in this indicator. These changes were combined with a decrease in the number of protective microflora of B. bifidum, B. lactis in the lumen of the colon. Molecular hydrogen under these conditions also had a protective effect (Fig. 3).

\section{Likerta scale, conventional units}
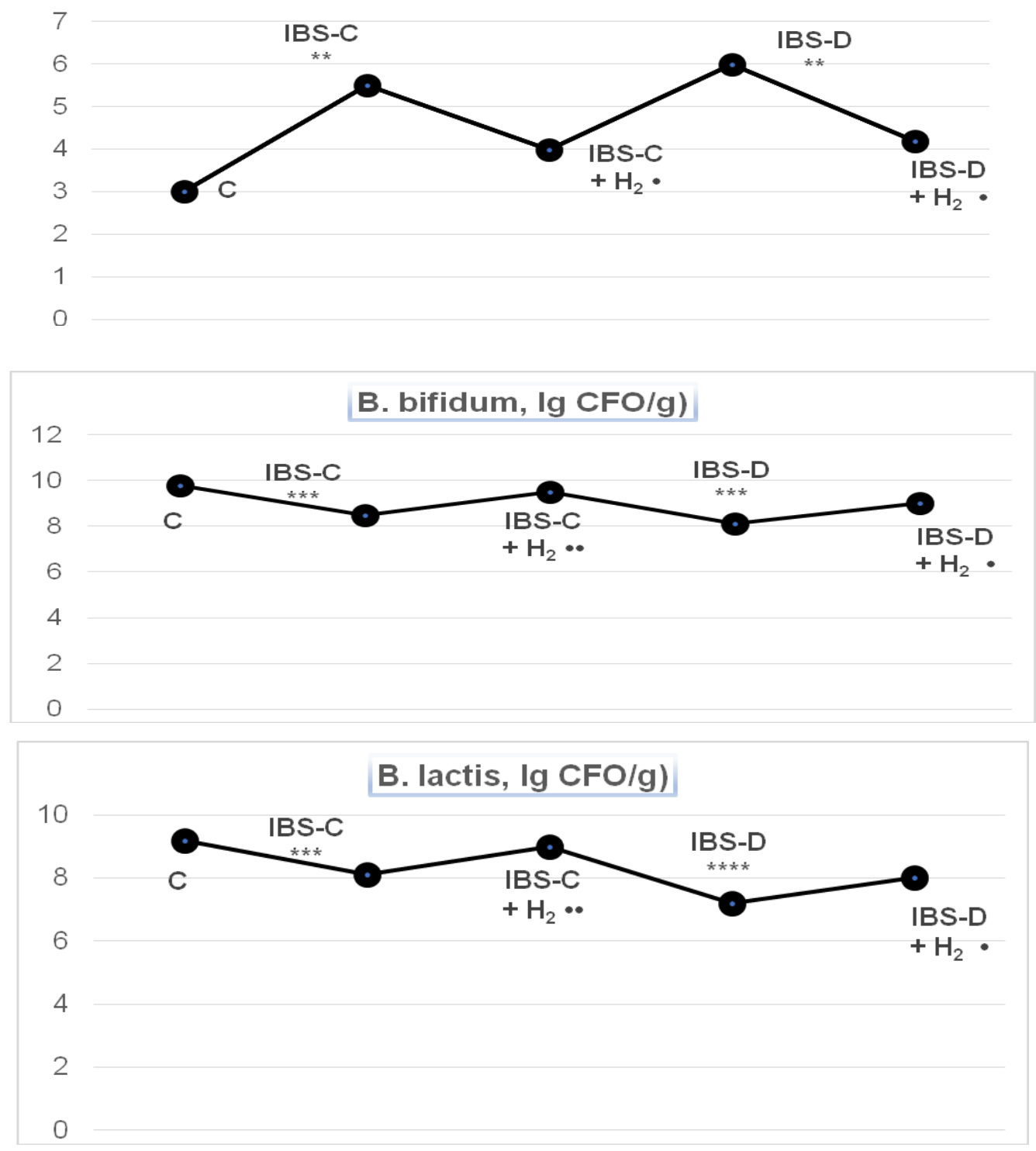

Fig. 3. Influence of molecular hydrogen $\left(\mathrm{H}_{2}\right)$ on the Likerta scale,

population levels of anaerobic microflora of the large intestine in patients with the development of irritable bowel syndrome with constipation (IBS-C) and diarrhea (IBS-D). The probability of differences was noted in comparison: before control $(\mathrm{C})$ : ** $-\mathrm{p}<0.02$; $* * *$ - $\mathrm{p}<0.01$; $* * * *-\mathrm{p}<0.001$; to irritable bowel syndrome with constipation and diarrhea $\bullet-\mathrm{p}<0,05 ; \cdot \bullet-\mathrm{p}<0,02$. 
DISCUSSION. The protective effect of molecular hydrogen is realized due to its high permeability and ability to neutralize hydroxyl radicals and peroxynitrite by reducing the manifestations of chronic stress, significant psychogenic maladaptation, anxiety response, which inhibited hyperplasia of APUD cells (EC-enterochromaffin), active substances: serotonin, motilin, substance P. Accordingly, there was no hyperfunction $[11,12]$ and the development of local inflammatory process with disorders of the barrier function of the intestine.

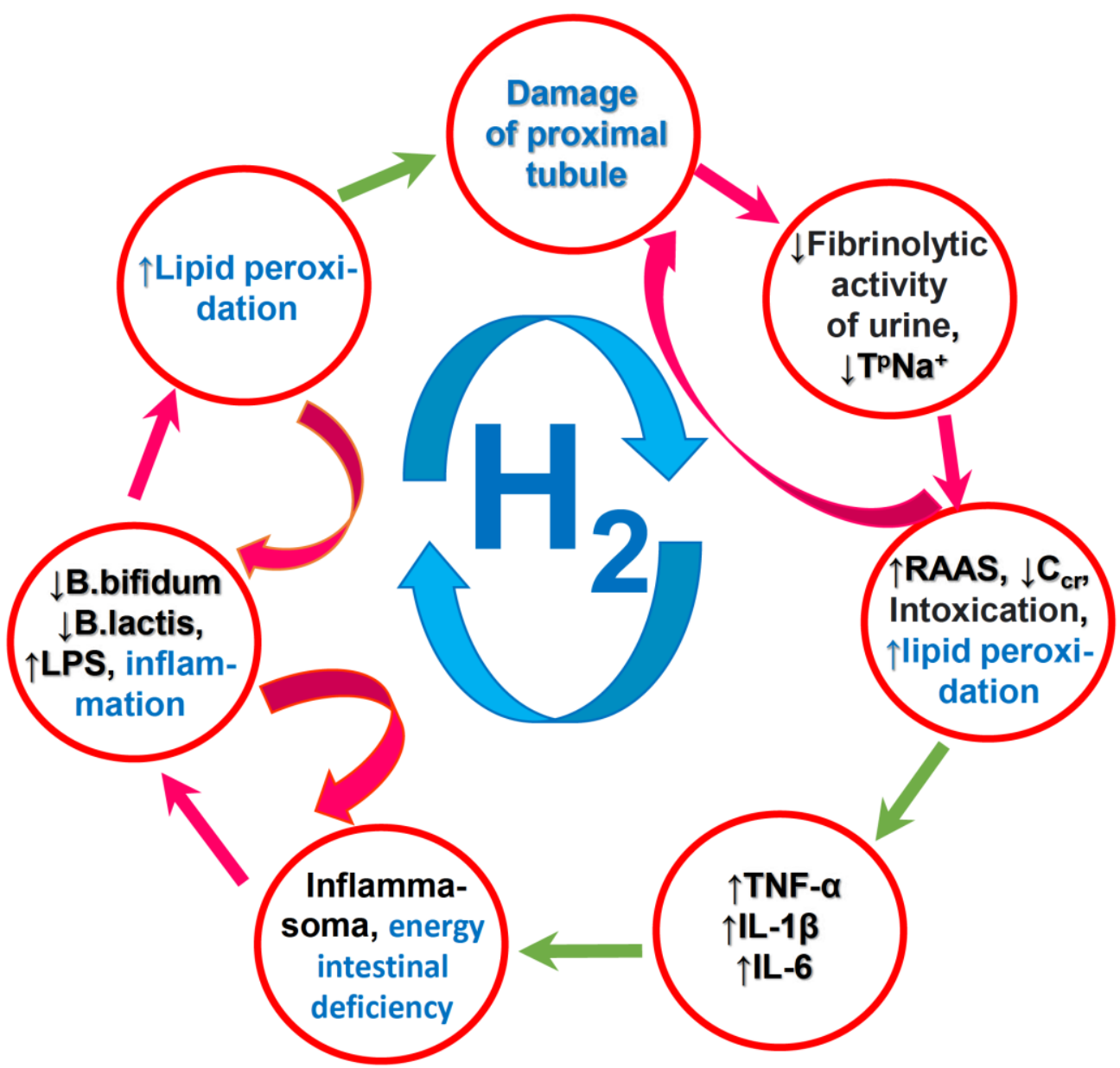

Fig. 4. Break of large and small vicious circles in damage to the proximal nephron and intestines in irritable bowel syndrome with constipation and diarrhea in patients using the antioxidant properties of molecular hydrogen $\left(\mathrm{H}_{2}\right) . \downarrow \mathrm{T}^{\mathrm{p}} \mathrm{Na}^{+}$- a decrease in the proximal reabsorption of sodium ions, $\downarrow C_{\text {cr }}$ - a decrease in the glomerular filtration rate, $\uparrow$ RAAS - an increase in the activity of the renin-angiotensin-aldosterone system, $\uparrow$ LPS increase in the lipopolysaccharide content in the intestine, $\uparrow$ TNF- $\alpha$ increased blood tumor necrosis factor alpha, $\uparrow I L-1 \beta$ increased blood interleukin 1 beta, $\uparrow$ IL- 6 increased blood interleukin 6 . 
Which did not lead to an increase in proinflammatory cytokines of tumor necrosis factor $-\alpha$, interleukin-1 $\beta$, interleukin -6 . Accordingly, there was no hyperfunction of the large intestine, its energy deficiency, increased use of B. Bifidum, B. Lactis to ensure the regeneration of the intestinal epithelium.

Due to the lack of decrease in the level of B. Bifidum, B. Lactis did not develop dysbacteriosis and there was no increase in lipopolysaccharide concentrations, activation of lipid peroxidation. As a result, the lipopolysaccharide did not interact with the CD14 receptor and the Toll-like receptor type 4 (TLR4) on monocytes (macrophages), which did not infiltrate the intestinal wall, which probably did not lead to the formation of an inflammasome (inflammation). - multiprotein complex [4], which is responsible for activating the inflammatory response. Inflammasoma promotes the maturation and secretion of proinflammatory cytokines interleukin- $1 \beta$ and interleukin 18 .

As a result of these processes, pyroptosis does not develop - a special type of programmed cell death. Inhibition of these processes did not lead to damage to the proximal tubule and inhibition of reabsorption of sodium ions [13, 14, 15], and, accordingly, did not create conditions for the formation of large and small vicious circles, when cause (etiological factors) causes the pathologic reactions (process) and then these reactions return to the first agent (etiological factor) and intensify of the combined pathological process (Fig. 4).

\section{CONCLUSION}

The protective effect of molecular hydrogen improves the functional state of the proximal renal tubule in irritable bowel syndrome due to its high permeability and selective antioxidant activity against hydroxyl radical and peroxynitrite, which contributes to the rupture of large and small vicious circles in the combined pathological process.

The prospect of scientific research is to conduct further research on the protective effect of molecular hydrogen in other diseases that are accompanied by the development of inflammation and activation of lipid peroxidation.

\section{References}

1. Dorofeev AE, Rudenko NN, Shvets NI, Snisarevskaya TP. Lechenie sindroma razdrazhennogo kishechnika. Mesto probiotikov [Treatment of the irritable bowel syndrome: the role of probiotics]. Suchasna hastroenterolohiia. 2018;2:77-82. (in Russian).

2. Kharchenko NV, Korulya IA, Kharchenko VV, Chervak IN. Sindrom razdrazhennogo kishechnika. Sovremennye podkhody k diagnostike i lecheniyu [Irritable 
bowel syndrome: modern approaches to the diagnosis and treatment]. Suchasna hastroenterolohiia. 2017;2:56-60. (in Russian).

3. Foxx-Orenstein, AE . Nove v terapiyi dlya likuvannya syndromu podraznenoho kyshechnyka: onovlennya dlya hastroenterolohiv [New and emerging therapies for the treatment of irritable bowel syndrome: an update for gastroenterologists]. Therapeutic Advances in Gastroenterology. 2016; 9; Issue 3: 354-375. DOI 10.1177/1756283X16633050 .

4. Liu, T, Cui, J. Rehulyatsiya inflammasomi shlyakhom autofahiyi [Regulation of inflammasome by Autophagy]. Advances in Experimental Medicine and Biology.2019; 1209: 109-123. DOI 10.1007/978-981-15-0606-2_7.

5. Rohovyi YuYe, Zlotar OV, Filipova LO. Patofiziolohiia hepatorenal'noho syndromu na poliurychnii stadii sulemovoi nefropatii [Pathophysiology of hepatorenal syndrome at the polyuric stage of sulmephic nephropathy]: monohrafiia. Chernivtsi: Misto; 2012. 200 s. ISBN 978-617-652-022-1. (in Ukrainian).

6. Li Ge, Ming Yang, Na-Na Yang, Xin-Xin Yin and Wen-Gang Song Molekulyarnyy voden': profilaktychnyy i likuval'nyy haz pry riznykh zakhvoryuvannyakh [Molecular hydrogen: a preventive and therapeutic medical gas for various diseases]. Oncotarget. 2017; 8:102653-102673. https://doi.org/10.18632/oncotarget.21130

7. Ohsawa I., Ishikawa M., Takahashi K., Watanabe M., Nishimaki K., Yamagata K., Katsura K., Katayama Y., Asoh S., Ohta S. Voden' diye yak terapevtychnyy antyoksydant shlyakhom vybirkovoho zmenshennya tsytotoksychnykh kysnevykh radykaliv [Hydrogen acts as a therapeutic antioxidant by selectively reducing cytotoxic oxygen radicals]. Nature $\begin{array}{llll}\text { Medicine. } & \text { 2007; } & \text { 688-694. } & \text { DOI: } 10.1038 / \mathrm{nm} 1577\end{array}$ https://www.nature.com/articles/nm1577.

8. Krishtal NV, Gozhenko AI, Sirman VM. Patofisiologiia nirok [Pathophysiology of kidney]. Odessa: Fenics, 2020: 144. ISBN 978-966-928-543-0. (in Ukrainian).

9. Bilookyi VV, Rohovyi YuIe. Rol' ushkodzhennia kyshechnyka u patohenezi rozlytoho zhovchnoho perytonitu [The role of intestinal damage in the pathogenesis of spill bilious peritonitis]. Shpytal'na khirurhiia. 2004;4:121-4. (in Ukrainian).

10. Nechytailo MIu, Bilookyi VV, Rohovyi YuIe. Zhovchnyi perytonit: patofiziolohiia i likuvannia [Biliary peritonitis: pathophysiology and treatment]. Chernivtsi: Bukrek; 2011. 296 s. ISBN 978-966-697-367-5. (in Ukrainian).

11. Gozhenko AI. Teoriya bolezni [Theory of the disease]: monografiya. Odessa: Feniks. 2018. 236 s. ISBN 978-966-928-200-2. (in Russian). 
12. Rohovyi YuYe, Bocharov AV, Kobylians'ka RM. Rol' al'ternatyvnykh metodiv navchannia pry vykladanni teoretychnykh ta klinichnykh medychnykh dystsyplin [The role of alternative teaching methods in the teaching of theoretical and clinical medical disciplines]. Medychna osvita. 2003;1:22-4. (in Ukrainian).

13. Rohovyi YuYe., Ariychuk OI., Gerush OV. Patofiziologicheskiy analiz roli peregruzki nefrona belkom v povrejdenii proxsimalnogo kanalca pri nefroliyiaze s razmerom kamney 0.6-1.0 sm [Pathophyisiology analysis overload nephron protein in the proximal tubule damage in the nephrolithiasis size stones of 0.6-1.0 sm]. Journal of Education, Health and Sport. 2017; 7 (7):1325-1335. eISSN 2391-8306. (in Ukrainian)

14. Pishak VP, Gozhenko AI, Rohovyi YuYe. Tubulo-itersticiyniy sindrom [Tubulointerstitial syndrome]. Chernivtsi: Medical Academy, 2002: 221. (in Ukrainian).

15. Gozhenko AI, Rohovyi YuYe, Fedoruk OS. et [al] "Prichovane" ushkodzenia proksimalnogo viddilu nephrona [The "hidden" damage of the proximal nephron]. Odessa med.j., 2001;5: 16-19. (in Ukrainian). 